\title{
Nutrient Concentrations in Macrophytes from Lotic and Lentic Environments of the Middle Parana
}

Concentraciones de nutrientes en macrófitas de ambientes ióticos y lénticos del río Paraná Medio, Argentina

Submitted on: May 14, 2019| Accepted on: February 12, 2020 | Published on: 27 May, 2021

Hernán Ricardo Hadad ${ }^{\mathrm{a}}$

Instituto de Química Aplicada del Litoral (IQAL), Universidad Nacional del Litoral (UNL), Consejo Nacional de Investigaciones Científicas y Técnicas (CONICET), Argentina

ORCID: 0000-0002-8664-9382

María Alejandra Maine

Instituto de Química Aplicada del Litoral (IQAL), Universidad Nacional del Litoral (UNL), Consejo Nacional de Investigaciones Científicas y Técnicas (CONICET), Argentina

ORCID: 0000-0001-5910-9420

María de las Mercedes Mufarrege

Instituto de Química Aplicada del Litoral (IQAL), Universidad Nacional del Litoral (UNL), Consejo Nacional de Investigaciones Científicas y Técnicas (CONICET), Argentina

ORCID: 0000-0003-4033-8607

Gisela Alfonsina Di Luca

Instituto de Química Aplicada del Litoral (IQAL), Universidad Nacional del Litoral (UNL), Consejo Nacional de Investigaciones Científicas y Técnicas (CONICET), Argentina

ORCID: 0000-0001-8509-7929

Gabriela Cristina Sanchez

Instituto de Química Aplicada del Litoral (IQAL), Universidad Nacional del Litoral (UNL), Consejo Nacional de Investigaciones Científicas y Técnicas (CONICET), Argentina

ORCID: 0000-0003-1878-9145

${ }^{*}$ Research article

${ }^{a}$ Corresponding author: E-mail: hhadad@fiq.unl.edu.ar

DOI: https://doi.org/10.11144/Javeriana.iued25.ncml

How to cite this article:

H. R. Hadad, M. A. Maine, M. M. Mufarrege, G. A. Di Luca, and G. C. Sanchez, "Nutrient concentrations in macrophytes from lotic and lentic environments of the Middle Parana River, Argentina," Ing. Univ., vol. 25, 2021. https://doi.org/10.11144/Javeriana.ived25.ncml 


\section{Abstract}

Objectives: The purpose of this work was to compare nutrient concentrations in water, sediment, and in plant tissues of Eichhornia crassipes and Panicum elephantipes from lotic and lentic environments of the Middle Parana River floodplain (Argentina). Materials and Methods: The study was carried out over an 18-month period. Plants, water, and sediment were collected in a lake (lentic environment) and in a river (lotic environment) from the Middle Parana River floodplain. Water and sediment were sampled in sites where $P$. elephantipes or E. crassipes were predominant and in sites without vegetation. Results and Discussion: The lentic and lotic environments dominated by E. crassipes showed the highest ammonium concentrations. The sediment from the lotic environment showed total phosphorus (TP) and total Kjeldahl nitrogen (TKN) concentrations significantly lower than those found in the sediment from the lentic environment. In the lentic environment, the sediment from the lake with the dominance of E. crassipes showed the highest TKN concentration, while the sediment from the lake dominated by $P$. elephantipes showed the highest TP concentration. For both plant species and for both environments, TKN and TP tissue concentrations were significantly higher in leaves in comparison with roots. Conclusions: Our results could be used to optimize the efficiency of treatment wetlands. Additionally, the use of locally available macrophytes as contaminant bioaccumulators in the Middle Parana River floodplain is completely feasible.

Keywords: wetlands, macrophytes, phosphorus, nitrogen.

\section{Resumen}

Objetivos: el objetivo de este trabajo fue comparar las concentraciones de nutrientes en agua, sedimento y en tejidos vegetales de Eichhornia crassipes y Panicum elephantipes estudiadas en ambientes lóticos y lénticos de la llanura aluvial del río Paraná Medio (Argentina). Materiales y Métodos: el estudio tuvo una duración de 18 meses. Plantas, agua y sedimento fueron colectados en una laguna (ambiente léntico) y en un río (ambiente lótico) de la llanura aluvial del río Paraná Medio. Agua y sedimento fueron colectados en sitios dominados por $P$. elephantipes o $E$. crassipes, y en sitios sin vegetación. Resultados y Discusión: los ambientes lénticos y lóticos dominados por E. crassipes mostraron las concentraciones de amonio más altas. El sedimento del ambiente lótico mostró concentraciones de fósforo total (PT) y nitrógeno total Kjeldahl (NTK) significativamente menores que las del sedimento del ambiente léntico. En este ambiente, el sedimento de la laguna dominada por E. crassipes mostró la concentración más alta de NTK, mientras que el sedimento de la laguna dominada por $P$. elephantipes mostró la concentración más alta de PT. Para ambas especies y ambos ambientes, las concentraciones de NTK y PT en tejidos vegetales fueron significativamente mayores en hojas que en raíces. Conclusiones: nuestros resultados podrán ser utilizados para optimizar la eficiencia de humedales de tratamiento. Además, el uso de macrófitas localmente disponibles como bioacumuladoras de contaminantes en la llanura aluvial del río Paraná Medio, es completamente factible.

Palabras clave: humedales, macrófitas, fósforo, nitrógeno. 


\section{Introduction}

Macrophytes are a key component in wetland ecosystems. As photosynthetic organisms, they are the main primary producers fixing energy and supplying oxygen for the other ecosystem components. Macrophytes have been studied locally and around the world in relation to different aspects such as response to contaminants, phytoremediation, and biomonitoring capacity [1]-[8]. Regarding biomonitoring, Bonanno and Vymazal [9] studied the accumulation of various elements in six species of macrophytes differing in biomass size, anatomy, life cycle, and ecology. These authors concluded that to know the capacity and efficiency of different macrophyte species can help to reduce the risk of contamination in the environment. Jenačkovic et al. [10] studied wetlands of the central Balkan Peninsula. These authors found that the abundance of Phalaris arundinacea, Scirpus lacustris, Carex riparia, and Eleocharis palustris increases when there is a decrease in the amount of nutrients in the water. Mayora, Schneider and Rossi [11] reported that soluble reactive phosphorus was positively correlated with dissolved organic matter, which increased during high waters in the Middle Parana River system. Studies carried out in the Middle Parana River floodplain have demonstrated that aquatic plants have shown fast growth, high productivity, and a wide response to floods and pollutant exposition [3], [12], [13]. Besides, there are numerous local studies focused on the plant responses and the efficiency of accumulation of nutrients and metals in tissues, carried out both, in natural and constructed wetlands, and in greenhouses [8], [13]-[23].

The monitoring of contaminant concentrations in different plant tissues, as well as the determination of pollutant concentrations in the sediments and the surrounding water in natural wetlands, is essential for the selection of locally available macrophytes to be used in constructed wetlands. It is necessary to know the nutrient accumulation efficiencies of macrophytes to be used in constructed wetlands to reach a suitable system efficiency. Besides, given that macrophytes have demonstrated high efficiency in contaminant accumulation in tissues and high tolerance, they could be efficient biomonitors of contaminants in the Middle Parana River floodplain.

The Parana River is the second largest river in South America. This river has an irregular hydrological regime. Floods may occur 1-3 times per year for periods of 3 weeks up to 4 months. Most of the Parana River main channel is surrounded by a wide floodplain. The floodplain consists of a large number of wetlands (shallow lakes, marshes, and riverine forests) where an abundant and varied aquatic vegetation develops. Eichhornia crassipes is one of the most abundant free-floating macrophytes in terms of cover, biomass, and productivity. Panicum elephantipes is also present in most water bodies, generally associated with E. crassipes. P. elephantipes is rooted in the bottom sediment, presenting aerial parts (stems and leaves) floating above the water surface. The aim of this work was to compare 
nutrient concentrations in water, sediment, and tissues of E. crassipes and P. elephantipes in lotic and lentic environments over time.

\section{Material and Methods}

\section{Sampling and Plant Study}

The study lasted 18 months, from July 2015 to December 2016. Plants, water, and sediment were collected in the lentic environment Los Matadores Lake ( $31^{\circ} 41^{\prime} 07^{\prime \prime} \mathrm{S}, 60^{\circ} 42^{\prime} 52^{\prime \prime} \mathrm{W}$ ) and in the lotic environment Correntoso River, which surrounds the studied lake. Both sites are located in the Middle Parana River floodplain at SW of Santa Fe city, Argentina (figure 1). This region exhibits diverse geomorphological units characterized by streams and shallow lakes [24].

The macrophyte species studied were $P$. elephantipes and E. crassipes. Water and sediment samples were collected by triplicate at environments dominated by $P$. elephantipes and $E$. crassipes and in sites without vegetation. The water samples were kept at $4{ }^{\circ} \mathrm{C}$. Sediments were sampled with an Eckman dredge considering the upper $10 \mathrm{~cm}$. Sediment samples were collected at 3-m intervals along three 15-m transects. Sediment samples were stored in plastic bags at $4{ }^{\circ} \mathrm{C}$. In each sampling, five replicates of plant samples were collected using a square frame of $50 \mathrm{~cm}$ on each side. All plants found in squares were harvested following the methodology proposed by Westlake [25] and APHA [26]. At the laboratory, plants were sorted into leaves and roots. In order to measure dry weight, plant material was dried at 105 ${ }^{\circ} \mathrm{C}$ until a constant weight was reached [26].

To determine nutrients in plant tissue, each plant species was collected with a square frame of $50 \mathrm{~cm}$ on each side by triplicate. Plants were split into roots and leaves.

\section{Figure 1. Localization of the sampling sites in the Middle Parana River floodplain}

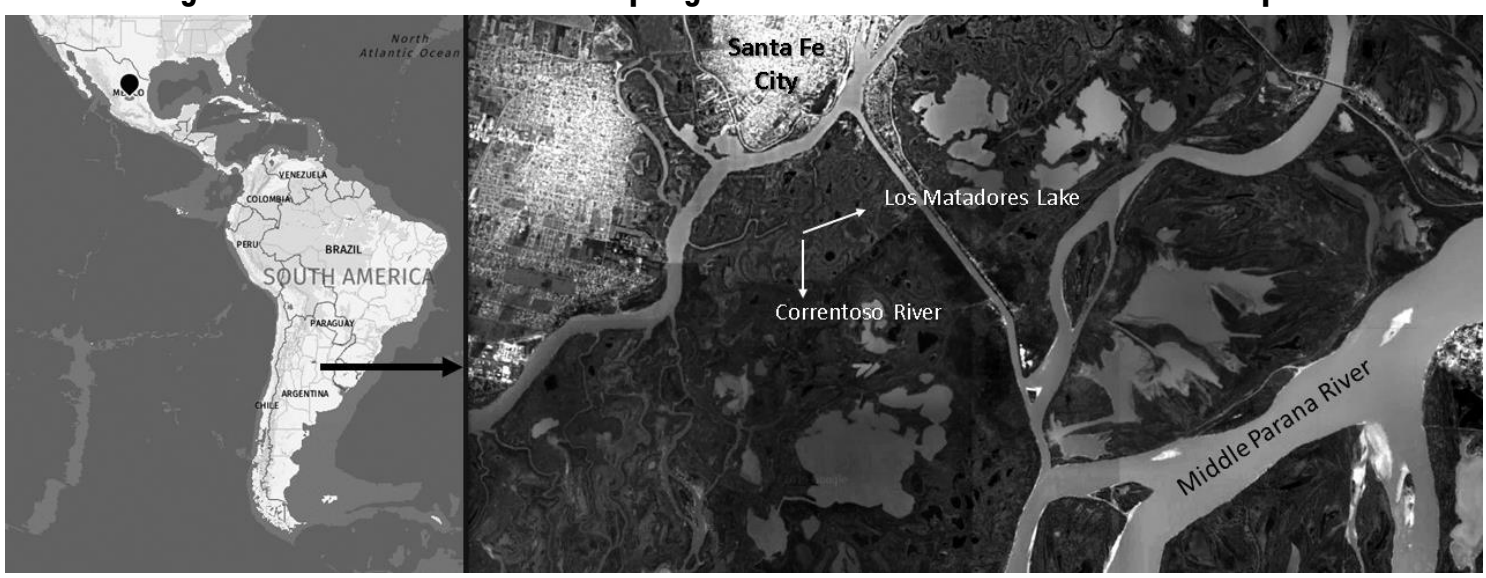

Source: Own elaboration 


\section{Chemical Analysis}

Water temperature and conductivity were measured in situ using a YSI 33 portable conductivity meter. Dissolved oxygen (DO) and $\mathrm{pH}$ were also measured in situ with a Horiba OM-14 portable meter and an Orion $\mathrm{pH}$-meter, respectively. Water samples were filtered through Millipore membrane filters $(0.45 \mu \mathrm{m})$. Chemical analysis was performed following APHA [26].

Plant samples were washed with tap and distilled water and subsequently plant and sediment samples were oven-dried at $60{ }^{\circ} \mathrm{C}$ for $48 \mathrm{~h}$. Total phosphorus (TP) concentrations were determined, after digestion with $\mathrm{HCl}: \mathrm{HNO}_{3}$ [27], by the colorimetric method of molybdenum blue [26], [28]. Total Kjeldahl nitrogen (TKN) in plant tissues and sediment were determined by the Semi-micro Kjeldahl method according to APHA [26]. After digestion with $\mathrm{HCl}: \mathrm{HNO}_{3}$ [27], $\mathrm{Na}$ and $\mathrm{K}$ concentrations in plant tissues were measured by flame atomic emission spectrometry, and $\mathrm{Ca}$ and $\mathrm{Mg}$ by flame atomic absorption spectrometry [26].

\section{Statistical Analysis}

Variance analysis (ANOVA) was carried out to evaluate significant differences in the different parameters measured in water, sediment, and plants. Factors were macrophyte species (3 levels: no vegetation- $P$. elephantipes- $E$. crassipes) and environments (2 levels: lotic-lentic). The samplings over time were considered as a completely randomized block. We made sure that plant samples were far enough in terms of space to be statistically independent. Duncan's Multiple Range Test was applied to differentiate means. A level of $\mathrm{p}$ $<0.05$ was used in all comparisons.

\section{Results and Discussion}

Table 1 shows the measured parameters in water during the study. Temperature, $\mathrm{pH}, \mathrm{DO}$, and conductivity values were in agreement with those previously reported for the studied wetlands [18]. There were no significant differences between the lentic and lotic environments for these parameters. Regarding ammonium, lotic and lentic environments dominated by E. crassipes showed the highest water concentrations. SRP and TP did not show significant differences between lotic and lentic environments or between the macrophyte dominance. The lentic environment dominated by E. crassipes showed the highest concentrations of ammonium, $\mathrm{Mg}$, and $\mathrm{K}$. 
Table 1. Characterization of water from the lotic and lentic environments dominated by $\boldsymbol{P}$. elephantipes and $E$. crassipes (mean and minimal and maximal values)

\begin{tabular}{c|ccc|ccc}
\hline \multirow{2}{*}{ Parameter } & \multicolumn{3}{|c|}{ Lentic environment } & \multicolumn{3}{c}{ Lotic environment } \\
\cline { 2 - 7 } & No vegetation & P. elephantipes & E. crassipes & No vegetation & P. elephantipes & E. crassipes \\
\hline Temperature & 21.1 & 21.2 & 20.5 & 21.1 & 21.2 & 21.3 \\
$\left({ }^{\circ} \mathrm{C}\right)$ & $(14.3-28.0)$ & $(14.3-28.0)$ & $(14.4-28.0)$ & $(11.1-27.0)$ & $(14.1-26.5)$ & $(14.1-26.5)$ \\
\hline \multirow{2}{*}{$\mathrm{pH}$} & 7.0 & 7.0 & 6.9 & 7.1 & 7.1 & 7.1 \\
& $(6.5-7.5)$ & $(6.5-7.5)$ & $(6.5-7.5)$ & $(6.5-7.5)$ & $(6.5-7.5)$ & $(6.5-7.5)$ \\
\hline Oxygen & 79.2 & 82.6 & 79.1 & 90.1 & 89.6 & 84.0 \\
$(\%$ saturation $)$ & $(58.0-95.0)$ & $(69.0-99.0)$ & $(42.0-101.0)$ & $(75.0-99.0)$ & $(73.0-101.0)$ & $(56.0-100.0)$ \\
\hline Conductivity & 134.7 & 134.3 & 131.1 & 137.2 & 138.5 & 140.6 \\
$(\mu \mathrm{mhos} \mathrm{cm}-1)$ & $(58.0-199.0)$ & $(58.0-203.0)$ & $(58.0-197.0)$ & $(60.0-283.0)$ & $(60.0-289.0)$ & $(60.0-295.0)$ \\
\hline $\mathrm{NH}{ }^{+}$ & 0.483 & 0.535 & 1.311 & 0.666 & 0.799 & 0.863 \\
$\left(\mathrm{mg} / \mathrm{L}^{-1}\right)$ & $(0.092-1.327)$ & $(0.005-1.602)$ & $(0.117-4.393)$ & $(0.039-2.889)$ & $(0.029-2.279)$ & $(0.029-4.419)$ \\
\hline $\mathrm{NO}{ }^{-}$ & 0.038 & 0.010 & 0.021 & 0.007 & 0.009 & 0.007 \\
$\left(\mathrm{mg} / \mathrm{L}^{-1}\right)$ & $(0.004-0.206)$ & $(0.001-0.041)$ & $(0.000-0.122)$ & $(0.001-0.015)$ & $(0.001-0.024)$ & $(0.000-0.021)$ \\
\hline $\mathrm{NO}{ }^{-}$ & 0.163 & 0.150 & 0.106 & 0.117 & 0.064 & 0.084 \\
$\left(\mathrm{mg} / \mathrm{L}^{-1}\right)$ & $(0.014-0.568)$ & $(0.013-0.659)$ & $(0.008-0.429)$ & $(0.019-0.331)$ & $(0.009-0.264)$ & $(0.012-0.288)$ \\
\hline $\mathrm{SRP}$ & 0.029 & 0.028 & 0.030 & 0.026 & 0.029 & 0.022 \\
$\left(\mathrm{mg} / \mathrm{L}^{-1}\right)$ & $(0.002-0.105)$ & $(0.004-0.051)$ & $(0.006-0.078)$ & $(0.004-0.045)$ & $(0.006-0.064)$ & $(0.004-0.047)$ \\
\hline $\mathrm{TP}$ & 0.547 & 0.238 & 0.199 & 0.305 & 0.205 & 0.298 \\
$\left(\mathrm{mg} / \mathrm{L}^{-1}\right)$ & $(0.038-1.072)$ & $(0.059-0.703)$ & $(0.067-0.453)$ & $(0.060-0.763)$ & $(0.047-0.545)$ & $(0.044-0.961)$ \\
\hline $\mathrm{Ca}$ & 7.867 & 7.60 & 7.87 & 7.40 & 7.35 & 7.47 \\
$\left(\mathrm{mg} / \mathrm{L}^{-1}\right)$ & $(3.0-14.0)$ & $(3.10-13.9)$ & $(3.20-2.9)$ & $(2.90-12.5)$ & $(2.90-12.1)$ & $(3.20-12.10)$ \\
\hline $\mathrm{Mg}$ & 3.567 & 3.45 & 5.788 & 3.378 & 3.544 & 3.344 \\
$\left(\mathrm{mg} / \mathrm{L}^{-1}\right)$ & $(0.200-10.70)$ & $(0.20-10.60)$ & $(1.90-17.80)$ & $(0.20-9.70)$ & $(0.200-10.0)$ & $(0.20-9.20)$ \\
\hline $\mathrm{Na}$ & 10.95 & 10.95 & 11.726 & 12.98 & 14.488 & 14.116 \\
$\left(\mathrm{mg} / \mathrm{L}^{-1}\right)$ & $(1.290-25.30)$ & $(2.290-26.45)$ & $(4.100-26.91)$ & $(1.290-37.72)$ & $(1.290-38.64)$ & $(1.290-38.41)$ \\
\hline $\mathrm{K}$ & 3.401 & 3.503 & 6.895 & 3.703 & 3.780 & 3.831 \\
$\left(\mathrm{mg} / \mathrm{L}^{-1}\right)$ & $(1.560-7.410)$ & $(1.56-7.41)$ & $(3.180-14.48)$ & $(1.950-7.930)$ & $(1.950-8.190)$ & $(1.950-7.410)$ \\
\hline
\end{tabular}

Source: Own elaboration

For the TP and TKN concentrations in sediments of the lotic environment, there were no significant differences between the sites dominated by the two macrophytes and the site without plants (figure 2). The sediment of the lotic environment showed TP and TKN concentrations significantly lower than those of the lentic environment. In the lentic environment, the sediment of the sites dominated by E. crassipes showed significantly higher TKN and significantly lower TP concentrations than those of the site dominated by $P$. elephantipes.

For both macrophytes and environments, significantly higher $\mathrm{TP}, \mathrm{TKN}$, and $\mathrm{Mg}$ concentrations were observed in leaves than in roots (figures 3 and 4), in agreement with previous studies carried out in the middle Parana River [13], [18]. E. crassipes showed TKN tissue concentrations significantly higher than those of $P$. elephantipes, in coincidence with 
the ammonium concentrations in water measured in the sites dominated by each macrophyte. TP tissue concentrations of both macrophytes were not significantly different between lotic and lentic environments.

Although TP and TKN concentrations in plant tissues were significantly higher than those of the sediment, considering the mass, the sediment is the main accumulator compartment [18]. The sediment plays an important role in the long-term cycling and storage of nutrients and contaminants in wetlands [13].

Figure 2. TKN and TP concentrations $(\mathrm{mg} / \mathrm{g})$ measured in sediment during the study
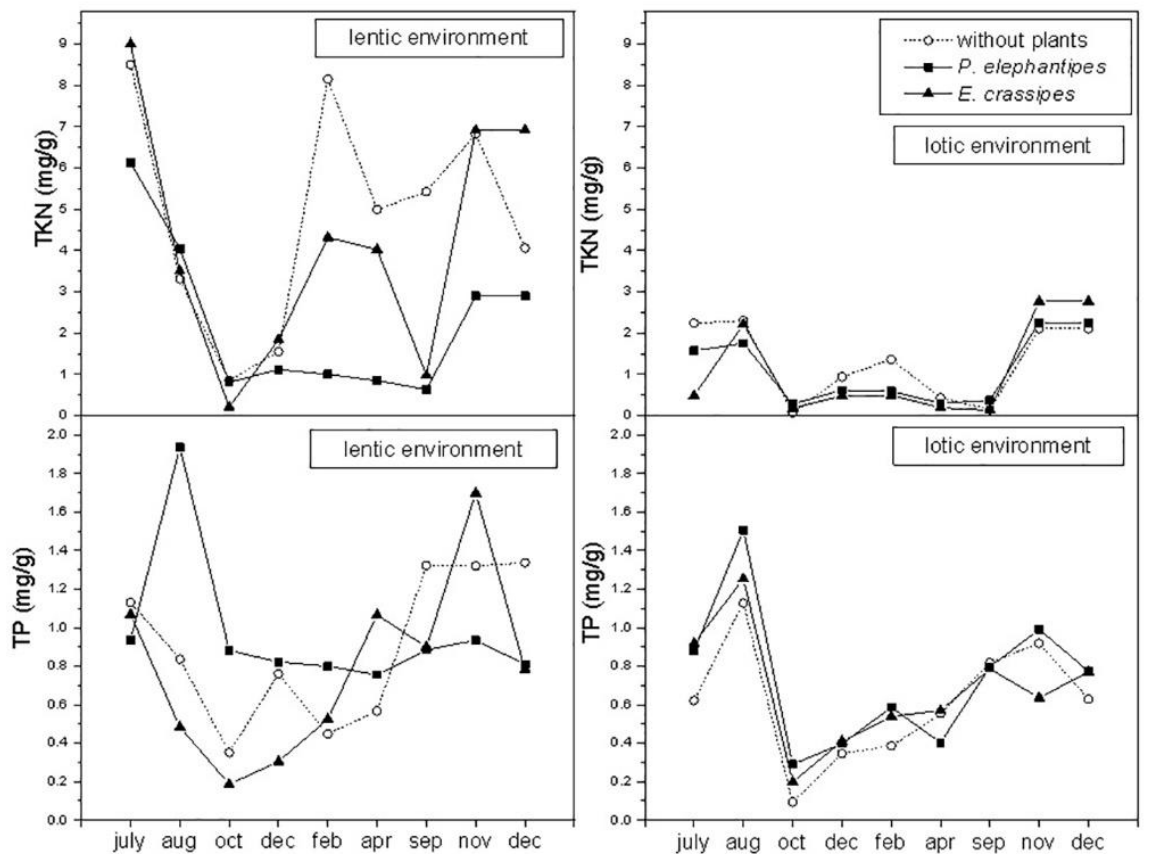

Source: Own elaboration

In systems without macrophytes, sediment replaces plants in the role of $\mathrm{P}$ removal. In natural water bodies, most of the P load is deposited in sediment where the adsorption to metallic oxides was identified as one of the main reactions [29]. The adsorptive capacity of the sediment for phosphate varies mainly due to changes in redox conditions related to the temperature cycle and the course of organic deposition [30]. Reina, Espinar and Serrano [31] found that the concentration of organic matter was significantly higher in the top sediment of sites covered by emergent vegetation than in their adjacent open-water sites. In summer, plant growth accumulates organic matter in bottom sediments, which decreases DO and redox potential of the sediment releasing $\mathrm{P}$ to the water column. Increased nutrients can also increase the growth of planktonic and benthic algae in wetlands, which, in turn, may compete with and inhibit macrophyte growth [32]. 
Figure 3. $\mathrm{Na}, \mathrm{K}, \mathrm{Ca}, \mathrm{Mg}$, TKN, and TP concentrations $(\mathrm{mg} / \mathrm{g}$ ) measured in leaves and roots of $E$. crassipes during the study

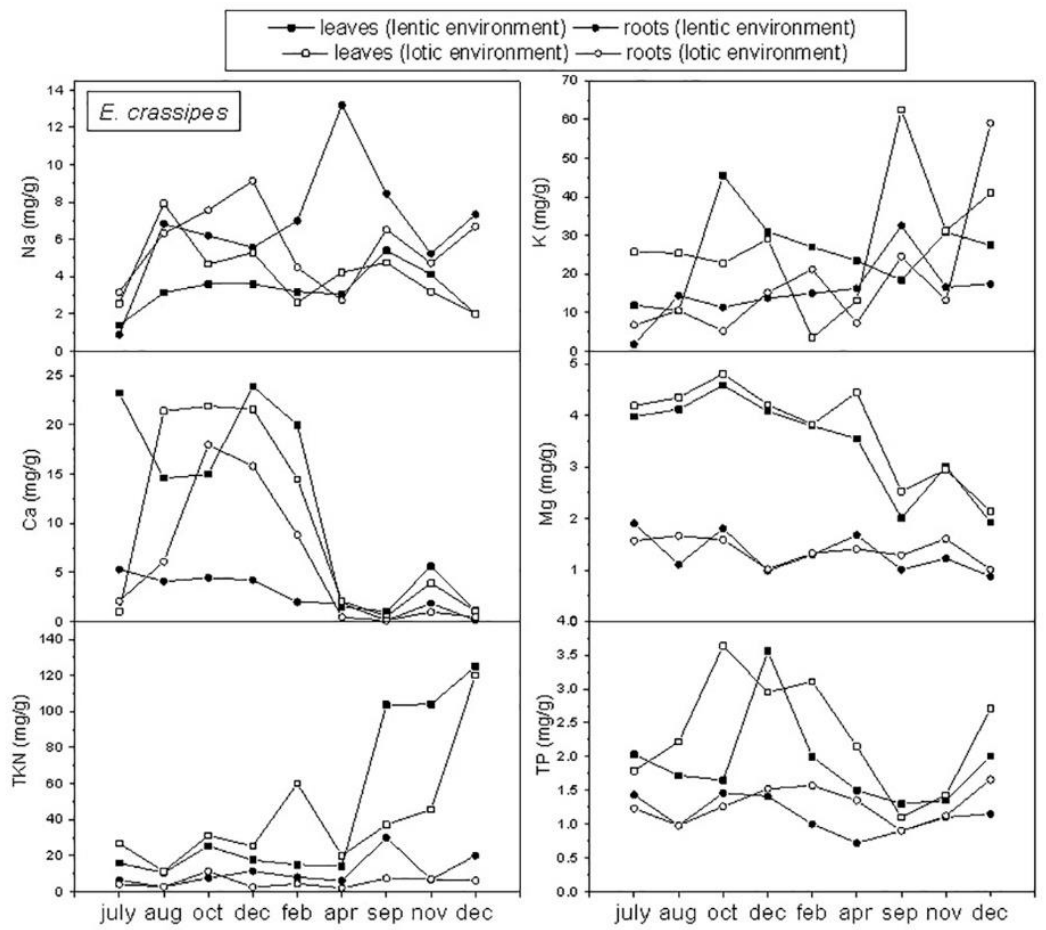

Source: Own elaboration

Macrophyte abundance and distribution in the Middle Parana River is determined by a complex process that involves hydrology, geomorphology, and changes in nutrient concentrations [33]. The different morphology and vegetation propagation of the two studied species influence the uptake and accumulation of nutrients in tissues [13]. Since the floating plants are not rooted in the bottom sediment, they obtain nutrients directly from the water column, enhancing nutrient accumulation into their biomass. Regarding $\mathrm{P}$, it is taken from the water as phosphate and it can be translocated from roots to aerial parts or vice versa, as it has been demonstrated in laboratory studies [34], [35]. E. crassipes is a free-floating plant with roots in direct contact with the water column. This species is propagated by extending stolons on the surface of the water. E. crassipes presents a high growth rate, high nutrient sorption capacity, and high concentrations of foliar nutrients [13]. E. crassipes root biomass was significantly lower in the lentic environment in comparison than that of the lotic environment (figure 5). This can be explained due to significantly lower nutrient concentrations in the lotic environment. The studied emergent macrophyte $P$. elephantipes develop dense stands on the coastal margins of streams with comparatively high-water depth and flux and is rooted on sandy bottoms. P. elephantipes reproduces mainly by occupying submersed and aerial spaces since it does not have aboveground rhizomes. The dry biomass of stems was significantly higher than that of the leaves and roots indicating the propagation mechanism of this macrophyte. The biomass of $P$. elephantipes did not show significant differences between the two environments (figure 5). In the case of emergent macrophytes, 
pollutant uptake by plants can be influenced by numerous sediment properties such as $\mathrm{pH}$, cation exchange capacity, clay content, organic matter content, and presence of other ions [41].

Figure 4. $\mathrm{Na}, \mathrm{K}, \mathrm{Ca}, \mathrm{Mg}$, TKN and TP concentrations $(\mathrm{mg} / \mathrm{g})$ measured in leaves and roots of $\boldsymbol{P}$. elephantipes during the study

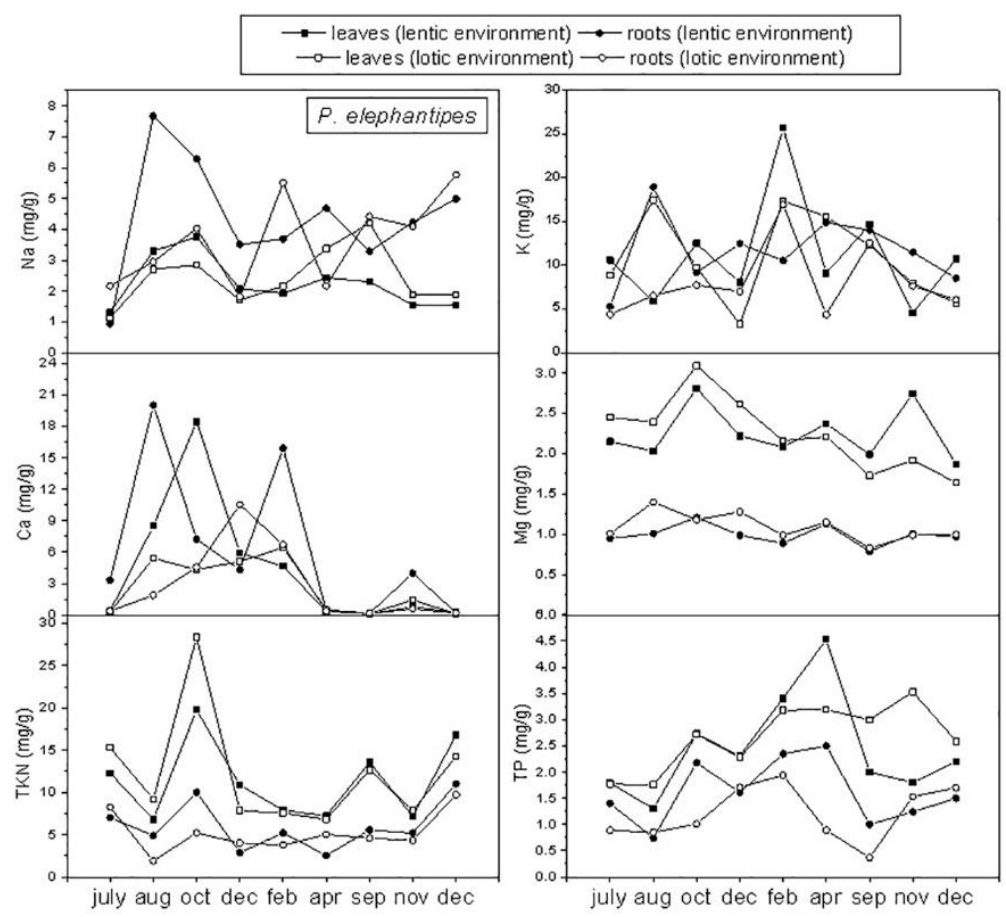

Source: Own elaboration

Plants growing in environments with high nutrient concentrations show shorter and coarser roots than those growing in water bodies with low nutrient concentrations. In the later, roots are larger and thinner, showing lower root biomass [36], [37]. High concentrations of nutrients in wetlands produce an increase in CSA of roots, stele, and total metaxylem vessels of macrophytes [16], [38], [39]. Therefore, exposure to an important nutrient supply allows a higher transport capacity. Wahl, Ryser and Edwards [38] demonstrated that a higher metaxylem vessel CSA represents a higher efficiency in the uptake and accumulation of contaminants in roots. Regarding ammonium, Piwpuan, Jampeetong and Brix [40] studied growth, morphological, and physiological responses of Actinoscirpus grossus to ammonium concentrations of $0.5,2.5,5,10$ and $15 \mathrm{mM}$ under hydroponic growth conditions. The relative growth rates of the plants were the highest at $2.5 \mathrm{mM}$ ammonium but significantly reduced at the ammonium treatments of 10 and $15 \mathrm{mM}$. The plant roots were stunted and produced subepidermal lignified-cell layers at ammonium exposure of 10 and $15 \mathrm{mM}$. 
Figure 5. Dry biomass $\left(\mathrm{g} / \mathrm{m}^{2}\right)$ measured in $E$. crassipes and $P$. elephantipes during the study
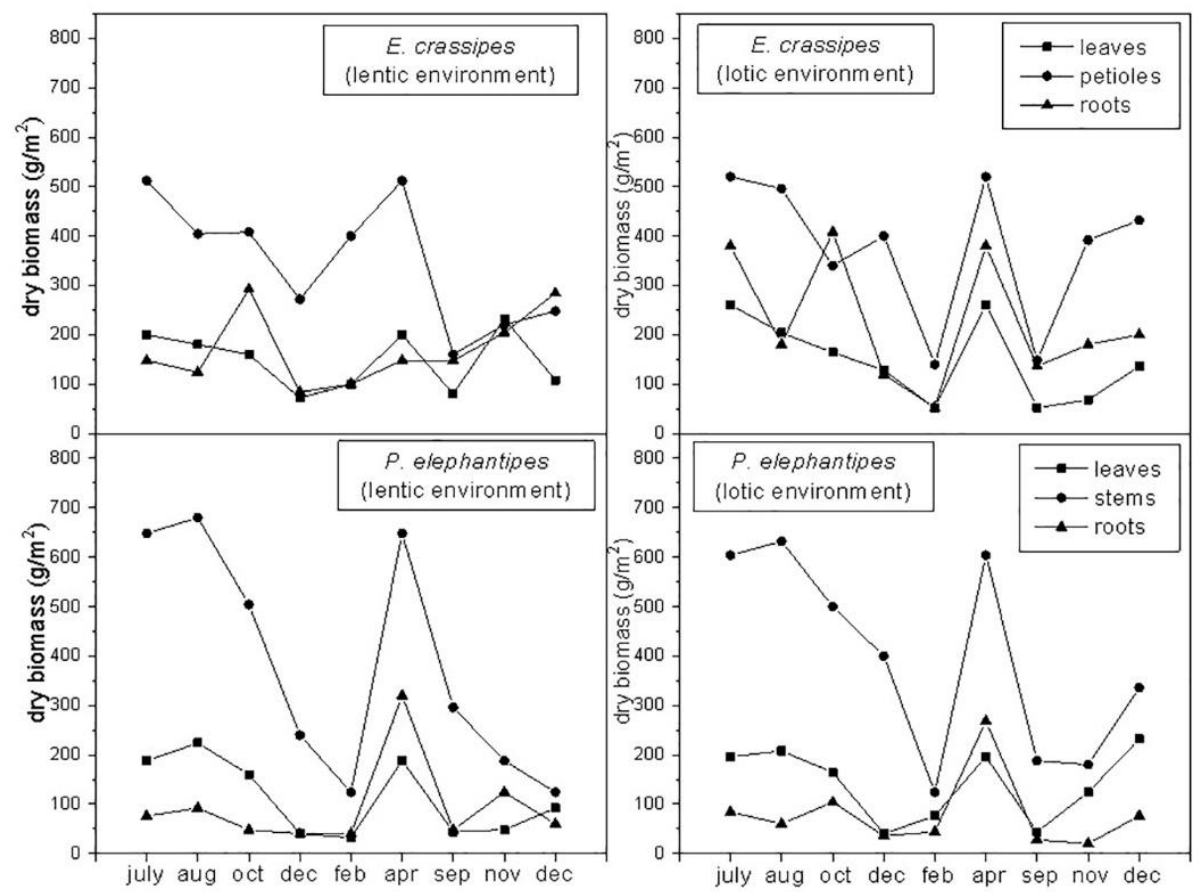

Source: Own elaboration

Although sediment accumulates contaminants and nutrients to a great extent, the advantage of using macrophytes in treatment wetlands is the possibility of being harvested, which leads to important removal rates of $\mathrm{P}$ in short times [42], [43]. The species that present high biomass, are the main P-bioaccumulators. Maine et al. [20] reported that in a constructed wetland E. crassipes carried out the highest P-removal in the studied period, due to its high productivity. Greenway [44] reported that emergent species of a constructed wetland in Australia had lower nutrient concentration but greater biomass and were able to store more nutrients per unit area of wetland. In order to achieve P removal from a natural wetland, the harvest of the floating species is proposed. Their population would recover quickly due to their high relative growth rate. However, in the case of treatment wetlands, emergent macrophytes are used because contaminant accumulation in the plant biomass could allow for phytoextraction from the system by harvesting, and phytostabilization by accumulation in the belowground tissues [45].

The emergent macrophytes in Middle Parana River floodplain typically show a seasonal variation, attaining the maximum biomass at the end of the growing period in late March. At a constructed wetland for wastewater treatment, where $\mathrm{P}$ is one of the contaminants to eliminate (sewage, municipal, agroindustry wastewaters, etc.), in order to maintain the efficiency of the system throughout the year, the use of floating as well as rooted species may be recommended. During the winter months, the rooted species could remove $\mathrm{P}$, whereas in summer the floating species would be the ones responsible for P removal. In order to achieve 
a complete $\mathrm{P}$ removal from the system, the harvest of the floating species during the summer months is proposed. Their population would recover quickly due to their high relative growth rate. Biomass harvested from CW can be used as a renewable energy source [46].

Studying the plant responses and contaminant accumulation in tissues may reveal specific response patterns. This has important implications for pollution control, biomonitoring, and for implementing ecological engineering projects such as constructed wetlands.

\section{Conclusions}

Both, the lentic and lotic environments dominated by E. crassipes showed the highest ammonium concentrations in water. TP and TKN concentrations in the sediment of the lotic environment were significantly lower than those of the lentic environment. The sediments of the lake dominated by E. crassipes showed a significantly higher TKN concentration, while the lake dominated by $P$. elephantipes showed a higher TP concentration. Nutrient concentrations were significantly higher in leaves in comparison with roots. Biological differences between the studied macrophytes affect the nutrient accumulation in tissues, determining if biomass harvest is an efficient method to remove nutrients from a wetland.

The obtained results could be used to optimize the efficiency of treatment wetlands. On the other hand, regarding the nutrient accumulation in plant tissues, the use of locally available macrophytes as contaminant bioindicators and bioaccumulators in the Middle Parana River floodplain is completely feasible.

\section{Acknowledgments}

The authors thank Consejo Nacional de Investigaciones Científicas y Técnicas (CONICET), Universidad Nacional del Litoral (UNL), and Agencia Nacional de Promoción Científica y Tecnológica for providing funds for this work.

\section{References}

[1] C. Villar et al., "Heavy metal concentrations in the Lower Paraná River and right margin of the Río de la Plata Estuary," Verh. Internat. Verein. Limnol., vol. 26, pp. 963-966, 1998.

[2] C. Villar, J. Stripeikis, M. Tudino, L. d'Huicque, O. Troccoli, and C. Bonetto, "Trace metal concentrations in coastal marshes of the Lower Paraná River and the Río de la Plata Estuary," Hydrobiologia, vol. 397, pp. 187-195, 1999. doi: 10.1023/A:1003730306880

[3] J. J. Neiff, A. Poi de Neiff, and S. A. L. Casco, "The effect of prolonged floods on Eichhornia crassipes growth in Paraná River floodplain lakes,” Acta Limnol. Brasilien., vol. 13, pp. 51-60, 2001. 
[4] A. J. Cardwell, D. W. Hawker, and M. Greenway, "Metal accumulation in aquatic macrophytes from south east Queensland, Australia," Chemosphere, vol. 48, no. 7, pp. 653-663, 2002. doi: 10.1016/S0045-6535(02)00164-9

[5] J. P. Coelho, M. E. Pereira, A. C. Duarte, and M. A. Pardal, "Contribution of primary producers to mercury trophic transfer in estuarine ecosystems: Possible effects of eutrophication," Mar. Pollut. Bull., vol. 58, no. 3, pp. 358-365, 2009. doi: 10.1016/j.marpolbul.2008.10.014

[6] P. Krems, M. Rajfur, M. Wacławek, and A. Kłos, "The use of water plants in biomonitoring and phytoremediation of waters polluted with heavy metals," Ecol. Chem. Eng., vol. 20, no. 2, pp. 353370, 2013. doi: 10.2478/eces-2013-0026

[7] G. Bonanno, J. A. Borg, and V. di Martino, "Levels of heavy metals in wetland and marine vascular plants and their biomonitoring potential: A comparative assessment," Sci. Tot. Environ., vol. 576, pp. 796-806, 2017. doi: 10.1016/j.scitotenv.2016.10.171

[8] X. Alonso et al., "Macrophytes as potential biomonitors in peri-urban wetlands of the Middle Parana River (Argentina)," Environ. Sci. Pollut. Res., vol. 25, nos. 3-4, pp. 312-323, 2018. doi: 10.1007/s11356-017-0447-7

[9] G. Bonanno and J. Vymazal, "Compartmentalization of potentially hazardous elements in macrophytes: Insights into capacity and efficiency of accumulation," J. Geochem. Explor., vol. 181, pp. 22-30, 2017. Available: https://doi.org/10.1016/j.gexplo.2017.06.018

[10] D. D. Jenačkovic, I. D. Zlatkovic, D. V. Lakušic, and V. D. Randelovic, "Macrophytes as bioindicators of the physicochemical characteristics of wetlands in lowland and mountain regions of the central Balkan Peninsula," Aquat. Bot., vol. 134, pp. 1-9, 2016. doi: 10.1016/j.aquabot.2016.06.003

[11] G. Mayora, B. Schneider, and A. Rossi, "Turbidity and dissolved organic matter as significant predictors of spatio-temporal dynamics of phosphorus in a large river-floodplain system," River Res. App., vol. 34, no. 3 pp. 629-639, 2018. doi: 10.1002/rra.3288

[12] V. H. Lallana, "Productividad de Eichhornia crassipes (Pontederiaceae) en una laguna isleña de la cuenca del Río Paraná Medio. I. Análisis del crecimiento," Bol. Soc. Arg. Bot., vol. 20, pp. 99-107, 1981. Available: https://botanicaargentina.org.ar/wp-content/uploads/2018/09/99-107010.pdf

[13] H. R. Hadad and M. A Maine, "Phosphorous amount in floating and rooted macrophytes growing in wetlands from the Middle Paraná River floodplain (Argentina)," Ecol. Eng., vol. 31, no. 4, pp. 251258, 2007. doi: 10.1016/j.ecoleng.2007.08.001

[14] H. R. Hadad, M. A. Maine, and C. A. Bonetto, "Macrophyte growth in a pilot-scale constructed wetland for industrial wastewater treatment," Chemosphere, vol. 63, no. 10, pp. 1744-1753, 2006. doi: 10.1016/j.chemosphere.2005.09.014

[15] H. R. Hadad, M. A. Maine, G. S. Natale, and C. A. Bonetto, "The effect of nutrient addition on metal tolerance in Salvinia herzogii," Ecol. Eng., vol. 31, no. 2, pp. 122-131, 2007. Available: https://doi.org/10.1016/j.ecoleng.2007.06.012

[16] H. R. Hadad, M. M. Mufarrege, M. Pinciroli, G. A. di Luca, and M. A. Maine, "Morphological response of Typha domingensis to an industrial effluent containing heavy metals in a constructed wetland," Arch. Environ. Contam. Toxicol., vol. 58, no. 3, pp. 666-675, 2010. doi: 10.1007/s00244009-9454-0

[17] H. R. Hadad, M. A. Maine, M. M. Mufarrege, M. V. del Sastre, and G. A. di Luca, "Bioaccumulation kinetics and toxic effects of $\mathrm{Cr}$, Ni and Zn on Eichhornia crassipes," J. Hazard. Mat., vol. 190, nos. 1-3, pp. 1016-1022, 2011. Available https://doi.org/10.1016/j.jhazmat.2011.04.044

[18] M. A. Maine, N. L. Suñe, and C. Bonetto, "Nutrient concentrations in the Middle Paraná River: Effect of the floodplain lakes," Arch. Hydrobiol., vol. 160, no. 1, pp. 85-103, 2004. doi: 10.1127/00039136/2004/0160-0085

[19] M. A. Maine, N. L. Suñe, and S. C. Lagger, "Chromium bioaccumulation: Comparison of the capacity of two floating aquatic macrophytes," Water Res., vol. 38, no. 6, pp. 1494-1501, 2004. Available: https://doi.org/10.1016/j.watres.2003.12.025 
[20] M. A. Maine, N. Suñe, H. Hadad, G. Sánchez, and C. Bonetto, "Nutrient and metal removal in a constructed wetland for wastewater treatment from a metallurgic industry," Ecol. Eng., vol. 26, no. 4, pp. 341-347, 2006. Available: https://doi.org/10.1016/j.ecoleng.2005.12.004

[21] M. A. Maine, N. L. Suñe, H. R. Hadad, G. Sánchez, and C. A. Bonetto, "Influence of vegetation on the removal of heavy metals and nutrients in a constructed wetland," J. Environ. Manag., vol. 90, no. 1, pp. 355-363, 2009. DOI: 10.1016/j.jenvman.2007.10.004

[22] M. A. Maine et al., "Sustainability of a constructed wetland faced with a depredation event," $J$. Environ. Manag., vol. 128C, pp. 1-6, 2013. doi: 10.1016/j.jenvman.2013.04.054

[23] M. A. Maine et al., "Long-term performance of two fee-water surface wetlands for metallurgical effluent treatment," Ecol. Eng., vol. 98, pp. 372-377, 2017. doi: 10.1016/j.ecoleng.2016.07.005

[24] M. Iriondo, "Quaternary lakes of Argentina," Palaeogeogr. Palaeocl., vol. 70, nos. 1-3, pp. 81-88, 1989. Available: https://doi.org/10.1016/0031-0182(89)90081-3

[25] D. F. Westlake, "Macrophytes", in A Manual on Methods for Measuring Primary Production in Aquatic Environments, R. A. Vollenweider, Ed. Oxford: Blackwell, 1974, pp. 32-42.

[26] APHA, AWWA, WEF, Standard Methods for the Examination of Water and Wastewater, 22nd ed. Washington D. C.: American Public Health Association, 2012.

[27] United States Environmental Protection Agency (USEPA), Method 200.2: Sample Preparation Procedure for Spectrochemical Determination of Total Recoverable Elements. Washington D. C.: Author, 1994. Available: https://19january2017snapshot.epa.gov/sites/production/files/201508/documents/method_200-2_rev_2-8_1994.pdf

[28] J. Murphy and J. Riley, "A modified single solution method for determination of phosphate in natural waters," Anal. Chim. Acta, vol. 27, pp. 31-36, 1962. Available: https://doi.org/10.1016/S00032670(00)88444-5

[29] L. Lijklema, "The role of iron in the exchange of phosphate between water and sediments," in Interactions Between Sediments and Fresh Water, H. L. Golterman, Ed. The Hague: Dr. W. Junk, 1977, pp. 313-317.

[30] L. Lijklema, "Considerations in modelling the sediment-water exchange of phosphorus," Hydrobiologia, vol. 253, pp. 219-231, 1993.

[31] M. Reina, J. L. Espinar, and L. Serrano, "Sediment phosphate composition in relation to emergent macrophytes in the Doñana Marshes (SW Spain)," Water Res., vol. 40, no. 6, pp. 1185-1190, 2006. Available: https://doi.org/10.1016/j.watres.2006.01.031

[32] C. Willis, and W. J. Mitsch, "Effects of hydrology and nutrients on seedling emergence and biomass of aquatic macrophytes from natural and artificial seed banks," Ecol. Eng., vol. 4, no. 2, pp. 65-76, 1995. Available: https://doi.org/10.1016/0925-8574(94)00046-8

[33] B. Schneider, E. R. Cunha, L. A. Espínola, M. Marchese, and S. M. Thomaz, "The importance of local environmental, hydrogeomorphological and spatial variables for beta diversity of macrophyte assemblages in a Neotropical floodplain," J. Veg. Sci., vol. 00, pp. 1-12, 2019. Available: doi: 10.1111/jvs. 12707

[34] J. A. de Marte, and R. T. Hartman, "Studies on absorption of 32P, 59Fe, and 45Ca by water-milfoil (Myriophyllum exalbescens Fernald)," Ecology, vol. 55, no. 1, pp. 188-194, 1974. doi: $10.2307 / 1934635$

[35] A. H. Eugelink, "Phosphorus uptake and active growth of Elodea canadensis Michx. and Elodea nuttallii," Water Sci. Technol., vol. 37, no. 3, pp. 59-65, 1998. Available: https://doi.org/10.1016/S0273-1223(98)00056-0

[36] M. M., Mufarrege, H. R., Hadad, and M. A. Maine, "Response of Pistia stratiotes to heavy metals (Cr, $\mathrm{Ni}$, and Zn) and phosphorous," Archiv. Environ. Contam. Toxicol., vol. 58, no. 1, pp. 53-61, 2010. Available: doi: 10.1007/s00244-009-9350-7 
[37] M. M., Mufarrege, H. R., Hadad, and G. A. di Luca, "Organic matter effects on the Cr(VI) removal efficiency and tolerance of Typha domingensis," Water Air Soil Pollut., vol. 229, no. 384, pp. 1-12, 2018.

[38] S. Wahl, P. Ryser, and P. J. Edwards, "Phenotypic plasticity of grass root anatomy in response to light intensity and nutrient supply," Ann. Bot., vol. 88, no. 6, pp. 1071-1078, 2001. Available: https://doi.org/10.1006/anbo.2001.1551

[39] M. V. Campanella, H. R. Hadad, M. A. Maine, and R. Markariani, "Efectos del fósforo de un efluente cloacal sobre la morfología interna y externa de Eichhornia crassipes (Mart.) Solms, en un humedal artificial”, Limnetica, vol. 24, no. 2, pp. 263-272, 2005. Available: http://www.limnetica.net/documentos/limnetica/limnetica-24-2-p-263.pdf

[40] N. Piwpuan, A. Jampeetong, and H. Brix, "Ammonium tolerance and toxicity of Actinoscirpus grossus: A candidate species for use in tropical constructed wetland systems," Ecotoxicol. Environ. Saf., vol. 107, pp. 319-328, 2014. Available: https://doi.org/10.1016/j.ecoenv.2014.05.032

[41] A. Kabata-Pendias, Trace Elements in Soils and Plants. Boca Raton, FL: Taylor \& Francis Group, 2011.

[42] P. R. Adler, S. T. Summerfelt, D. M. Glenn, and F. Takeda, "Evaluation of a wetland system designed to meet stringent phosphorus discharge requirements," Water Environ. Res., vol. 68, no. 5, pp. 836840, 1996. doi: 10.2175/106143096X127839

[43] M. C. Panigatti, and M. A. Maine, "Influence of nitrogen species (NH4+ and NO3-) on the dynamics of P in water-sediment-Salvinia herzogii systems," Hydrobiologia, vol. 492, nos. 1-3, pp. 151-157, 2003. doi: 10.1023/A:1024860213797

[44] M. Greenway, "Suitability of macrophytes for nutrient removal from surface flow constructed wetlands receiving secondary treated sewage effluent in Queensland, Australia," Water Sci. Technol., vol. 48, no. 2, pp. 121-128, 2003.

[45] T. B. Brezinová, and J. Vymazal, "Evaluation of heavy metals seasonal accumulation in Phalaris arundinacea in a constructed treatment wetland," Ecol. Eng., vol. 79, pp. 94-99, 2015. doi: 10.1016/j.ecoleng.2015.04.008

[46] T. Avellán, and P. Gremillion, "Constructed wetlands for resource recovery in developing countries," Renew. Sustain. Energy Rev., vol. 99, pp. 42-57, 2019. doi: 10.1016/j.rser.2018.09.024 